\title{
The demise of serial verbs in South Efate
}

\author{
Nicholas Thieberger
}

\begin{abstract}
The literature on Oceanic verb serialisation is replete with examples from Vanuatu. Crowley (2002a) noted that what he called the dissolution of serial verbs was observable in languages of southern Vanuatu, in particular in his study of Sye of Erromango. I will show that serial verbs in South Efate ${ }^{1}$ have followed a similar path to that described for Sye and also for Anejom by Lynch (2004a), including verb compounding, the use of directional particles, and an "echo-subject" construction. What is particularly interesting in South Efate is the development of a set of auxiliary verbs in a preverbal slot that carry out many of the functions associated with serial verb constructions. South Efate has been described as the southernmost of the Proto North-Central Vanuatu subgroup, but the features outlined here suggest a more complex relationship with southern languages than was previously considered.
\end{abstract}

\section{Introduction}

Languages of Vanuatu are well represented in the literature on Oceanic serial verbs, and work on serial verbs of languages of Vanuatu includes that on Paamese (Crowley 1987b), Lewo (Early 1993), Namakir (Sperlich 1993), Tamambo (Jauncey 1997), Lolovoli (Hyslop 2001), Araki (François 2002) and Mwotlap (François 2004). Crowley's (2002a) general survey of serial verbs in Oceanic languages also focuses on several languages of Vanuatu and, together with his 1987 work on Paamese, has been a major contribution to our knowledge in this area. He observed that, within Vanuatu, there is a difference in the way in which languages allow verbs to combine such that the classic types of serial verb constructions (SVCs) he described for Paamese are not present, for example, in the languages of Erromango in southern Vanuatu. South Efate,

\section{Notes}

1. There is no indigenous name for the language which is referred to locally as nafsan ('language' or 'story'). I will follow the practice established by Tryon (1976) and Clark (1985) of referring to the collection of dialects spoken in the south of Efate as South Efate. The current work is the result of three periods of fieldwork in the villages of Eratap and Erakor in South Efate, Vanuatu between 1995 and 2000. Thanks to Manuel Wayane, Endis Kalsarap, Kalsakar Wayane and many other speakers of South Efate for their assistance, and to Anna Margetts, Nick Evans, John Lynch and two anonymous reviewers for comments on an earlier draft of this paper that have significantly improved it. Fieldwork on South Efate was supported by the Department of Linguistics \& Applied Linguistics of the University of Melbourne and further work has been funded by an Australian Research Council Postdoctoral Fellowship. 
the southernmost language of central Vanuatu, fits into this cline from north to south in that it has little serialisation. In this paper I will show that South Efate has lexicalised some nuclear layer SVCs to form compound verbs and grammaticalised a set of auxiliary verbs and directional particles that perform the functions associated with nuclear layer SVCs in languages to the north.

\section{South Efate}

South Efate is an Oceanic language with up to 6000 speakers on the island of Efate in central Vanuatu and has been regarded as being part of the group of languages descended from Proto Central Vanuatu (Lynch 1994). However, more recent work (Lynch 2001a) proposes that South Efate shares a number of innovations with languages of southern Vanuatu that make for a potential subgroup for which Lynch has coined the name Proto Erakor-Kwenyii (a high level subgrouping that takes in Proto New Caledonia) as shown in Figure 1. Lynch (2004b) points to the complexity of links between South Efate and languages both to the north and to the south, concluding that settlement patterns for this area may have involved leapfrogging islands and perhaps the settlement of New Caledonia from Efate.

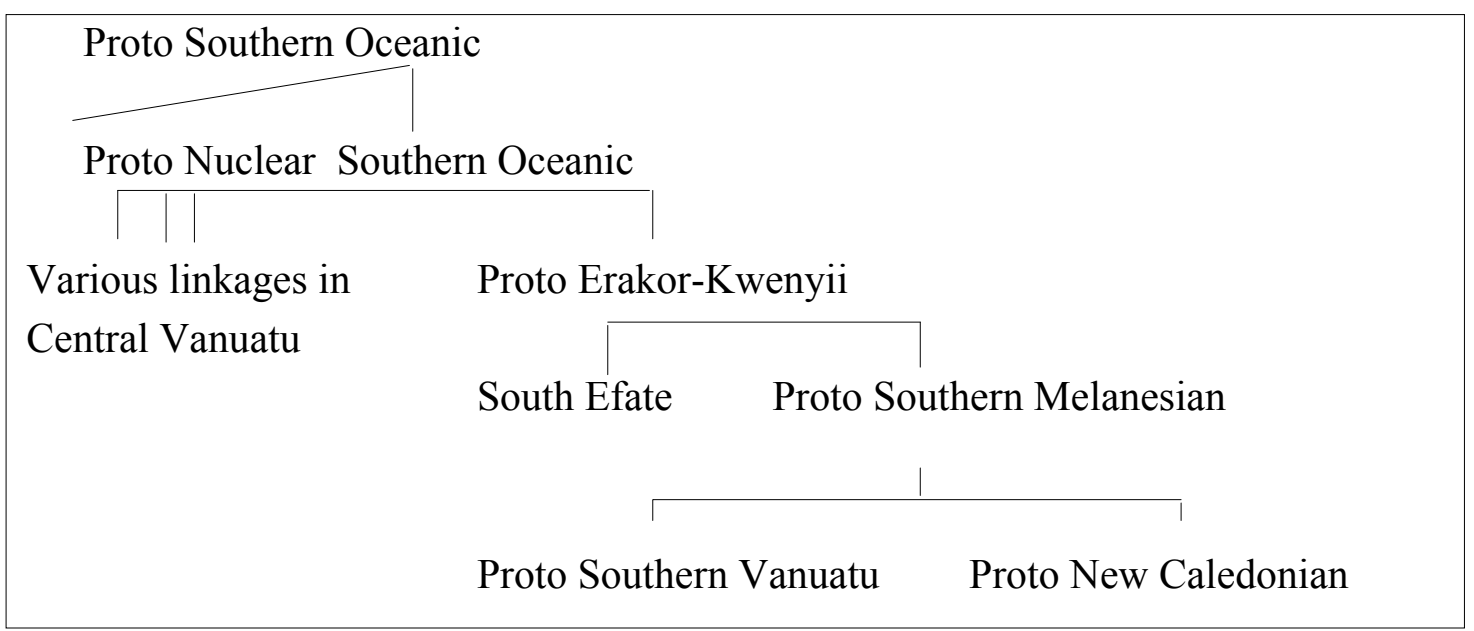

Figure 1: Southern Oceanic subgrouping (Lynch 2001a: 165)

South Efate is an SVO language in which the only obligatory parts of a clause are the proclitic subject and the verb. The verb may be preceded by several items including particles encoding aspect, polarity, and reflexive/reciprocal and auxiliary verbs, all of which form the preverbal complex (PVC). The maximal preverbal complex is illustrated by the schema below, which shows that all elements of the preverbal complex are optional.

$$
\text { ASP } \quad\left\{\begin{array}{c}
(\mathrm{ASP})(\mathrm{DUR})(\mathrm{NEG}) \\
(\mathrm{NEG})(\mathrm{CND} / \mathrm{may})
\end{array}\right\}\left\{(\mathrm{AUX})\left(\begin{array}{c}
\mathrm{RR}+\mathrm{DP} \\
\mathrm{QUANT}
\end{array}\right)\right\}
$$$$
\text { DUR Durative }
$$ 
NEG Negation, formed by two parts, the first preceding the negated proposition and the second (NEG2) following it. The first part of the negation may also occur within the AUX, depending on the scope of the negation.

$\mathrm{CND} /$ may Conditional/'may'

AUX Auxiliary verb

RR+ DP Reflexive/reciprocal and direct possessive suffix

QUANT Quantifier

The frequency of use of types of verb combinations, compared to simple verbs, is presented in Table 1 which shows that predicates occur most often as simple verb stems. There were 546 predicate positions in this dataset, and an additional 107 occurrences of auxiliary verbs. In $\$ 3.2 .4$., I argue that auxiliary verbs perform functions that are associated with SVCs in other North-Central Vanuatu languages. Compare the South Efate results with Crowley's figures for Paamese where about $25 \%$ of verbs appear in a serial verb construction (Crowley 2002a: 22).

Table 1: Sample texts, predicate types ${ }^{2}$

\begin{tabular}{lccccc}
\hline & $\begin{array}{c}\text { Single } \\
\text { main verb }\end{array}$ & $\begin{array}{c}\text { Compound - } \\
\text { asymmetrical }\end{array}$ & $\begin{array}{c}\text { Compound - } \\
\text { symmetrical }\end{array}$ & Totals & AUX \\
\hline Narratives & 263 & 7 & 13 & 283 & 54 \\
Court hearing & 252 & 0 & 11 & 263 & 53 \\
Total & 515 & 7 & 24 & 546 & 107 \\
\hline
\end{tabular}

Crowley (2002a) observes that there is great variation in the way serial verb constructions are expressed in particular languages. Within Vanuatu he points to the difference between northern languages (including Paamese), which display comparatively rich serialisation, and the southern languages of Tanna and Erromango, where serialisation plays a relatively minor role. Between these lies South Efate, in Central Vanuatu, in which functions associated with nuclear layer SVCs in other languages are carried out by non-SVC constructions.

Crowley's discussion of the "dissolution" of SVCs in Oceanic (2002a: 169) points to several means by which historical SVCs have become grammaticalised into other constructions. It is significant that features that Crowley cites as being indicative of the move away from verb serialisation are reflected in South Efate today, specifically: the development of compound verb forms (section 3.1) which exhibit morphological grammaticalisation (Crowley 2002a: 176); the use of auxiliary verbs (section 3.2.4) to encode modality, direction and other features associated with serial verb constructions in other languages; and the use of directional particles that occur after locational nouns rather than in verb sequences (section 3.2.3). Crowley discusses the use of an echosubject marker in the Erromangan language Sye as a means of concatenating verbs and clauses that is not a core-layer SVC (Crowley 2002a: 201-208) and South Efate also has an echo-subject marker of the form $\mathrm{kai}^{3}$ that links verbs or clauses. Lynch's (2004) discussion of Anejom clauses reflects facts similar to the South Efate data, including the

2. The texts counted are made up of five monologic narratives by five different speakers and a 16 minute extract from a court hearing with multiple interlocutors. In all cases there is an overwhelmingly strong preference for single verb stems. The terms 'compound- asymmetrical' and 'compound-symmetrical' are discussed in $\$ 3.1$.

3. For further details see Thieberger (2004: 117). 
reliance on verb compounding, an echo-subject construction and the use of directional particles or suffixes.

\section{Types of verb combinations in South Efate}

Before proceeding we need to outline what kinds of verb combinations occur in South Efate. By doing this we can eliminate a number of candidates for serial verb constructions, which we will see are not a feature in the South Efate corpus. In Table 2 are types of potential verb combinations, starting with compound verbs (i), which are formed by two contiguous stems, usually, but not exclusively, formed by verb stems. The combinations of verb and adverb, noun or preposition are included here as they function to form a compound verb in the same way as a verb + verb combination. Adverbial modification of verbs (ii) can be distinguished from verb + verb combinations as adverbs form a distinct class. The distinction between compound verbs and verb + adverbs is centred on the degree of cohesion between the two stems. Compound forms are more conventionalised, typically forming lexical items as discussed in section 3.1 below. Prepositions and directional particles (iii) have distributional characteristics that make it clear that they are not serial verbs. Auxiliary verbs (iv) can also form contig-uous verb sequences, but with a structural boundary between them and the main verb that prevents them being treated as serial verbs. Categories (ii) to (iv) are discussed below under the heading "Pseudo serial verbs" (section 3.2.), each plausibly grammaticalised from serial verb constructions.

Table 2: Types of verb combinations

\begin{tabular}{llll}
\hline & & Structure & Type \\
\hline Compounds & & Verb + Verb & Asymmetrical \\
& i & Verb + Adverb & compound \\
& Verb + Noun & Symmetrical \\
Cerb + Preposition & compound \\
Pseudo & ii & modifier + Verb & Adverbial \\
serial verbs & & Verb + modifier & modification \\
& & & V+Directional particles \\
& iii & S=V de-verbal adjunct & V+Preposition/ \\
& & & prepositional verb \\
& & Auxiliary & Auxiliary \\
& iv & Verb $)^{\mathrm{n}}+$ Verb &
\end{tabular}

\subsection{Verb compounds}

Verb compounds consist of two stems in sequence (verb1 + stem2), occupying the same slot as a single verb stem and with a single PVC and OBJ suffix as in the following schema:

(2) $\quad \mathrm{S}=\mathrm{PVC}$ V X $-(\mathrm{TR}=\mathrm{OBJ})$ 
The second slot of compounds is not restricted to verbs but may be a noun (pregnafnag 'make food') or a preposition (e.g. to-reki 'wait for') or an adverb (mro-perkat 'really think $>$ remember'). Examples of verb + verb combinations will be presented below. The word class of the resulting compound is a verb. This level of verb combining is similar to that called nuclear-layer in descriptions of other Oceanic languages (see Crowley 2002a). The fact that the second part of compounds can be either verbal or nonverbal is evidence of their non-serialised nature.

Compounds function as single phonological words. An illustration of this degree of compounding is that a productive process of medial vowel reduction (MVR), which only functions word-internally, applies to eligible compounds when the second verb has a transitive suffix and OBJ suffix. The addition of these suffixes creates new syllable boundaries which indicates that the compound is acting as a single word for stress assignment purposes. For example, the destressed mid vowel /o/ is elided in (3a), where the compound form kul-kor takes the 3PL.OBJ suffix -or and thus becomes resyllabified as kul.ko.ror undergoing MVR to become 'kul-kror.

(3) a. kul 'to blanket' + kor 'to enclose' -o-r '3PL.OBJ' 'kul-kor-o-r>kulkror 'to cover'

b. mro 'to think' + pir 'dis-, NEG' -i-k '2SG.OBJ' 'mro-pir-i-k>mroprik 'to think badly of you'

and kill'

c. wat 'to hit' + pun 'to kill', -i-ø '3SG.OBJ' 'wat-pun-i-ø>watpni 'to hit

This diagnostic only works occasionally since not all of the V2 stems in Tables 3 and 4 below are eligible environments for MVR to occur. Thus the compounds in (4) form phonological words which take a single object suffix, but do not provide an eligible environment for MVR. For example in (4a) MVR is blocked by the presence of a consonant cluster /gt/; in (4b) MVR does not apply as the unstressed syllable contains a low vowel (ta), and in (4c) MVR is blocked by the presence of a consonant cluster $/ \mathrm{mnr} /{ }^{4}$ them'

(4) a. nrog 'to hear' + tae 'to know' $+r$ '3PL.OBJ' 'nrogtaer 'to understand

b. ta 'to hug' + sok 'to collide' $+i ø$ '3SG.OBJ' 'tasoki 'to hug it tightly'

c. pam 'to eat' + nrog 'to hear' $+o \varnothing$ '3SG.OBJ' 'pamnrogo 'to taste it'

As examples of compound verbs, fis-ktof 'to break by whipping', and preg-sa 'to do bad' in (5) each have one subject marker and take a single object suffix.

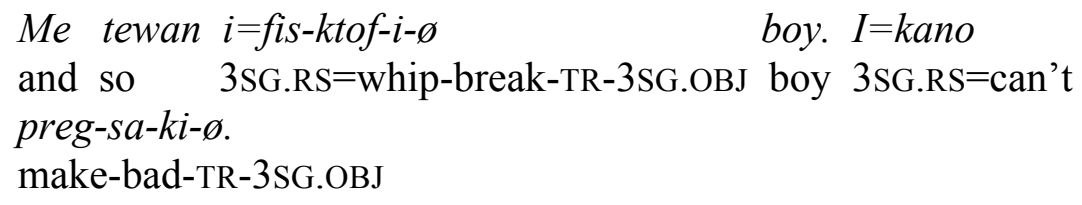

4. $n r$ is a digraph representing the phonemic prenasalised trill. 
A defining characteristic of compound verbs is that no $\mathrm{TAM}^{5}$ or polarity item can intervene between the verb stems. A corollary is that both verbs in these constructions share TAM and polarity. Thus the compound verb pes-top 'talk-big' in (6a) cannot be separated by the second part of the discontinuous negation as in (6b).

(6) a. Ssst. Ku=ta pes-top mau. Nlaken kin i=min nmalok. Shh 2SG.RS=NEG talk-big NEG2 because REL 3SG.RS=drink kava 'Shh. Don't talk loudly! Because he is drinking kava.' (98007bz, 719.8, 724.3)

b. $\quad * u=$ ta $\quad$ pes mau top
2SG.RS=NEG talk NEG2 big

We can further divide the group of compound verbs on the basis of syntactic symmetry, that is, what kinds of verbs can fill each verb slot. Symmetrical compounds are those in which both parts of the compound come from an open class of verbs and so both verbs can operate in other contexts as verbs on their own (following Aikhenvald 1999: 472). Asymmetrical compounds are made up of a verb plus a second morpheme which cannot function as a verb on its own. These second parts of asymmetrical compounds can include nouns and adverbs as will see in section 3.1.2 below.

\subsubsection{Symmetrical compounds}

Symmetrical compounds are those for which both verbs are attested as occurring as main verbs. A list of some common types of symmetrical compounds is given in Table 3. The first verb in these compounds can be intransitive (mro 'to think', kal 'to dress'), semitransitive ( $a k$ 'to ascend') or ambitransitive ( $k a t$ 'to bite', nrog 'to hear'). The second verb in the present data is always ambitransitive.

Table 3: Examples of symmetrical verb compounds

\begin{tabular}{|c|c|c|c|c|}
\hline \multicolumn{2}{|c|}{ Verb1 } & \multirow{2}{*}{$\begin{array}{l}\text { Verb2 } \\
+ \text { nrog to feel, } \\
\text { hear }\end{array}$} & \multicolumn{2}{|c|}{ Compound form } \\
\hline kal & to dress & & kalnrog & to try clothes \\
\hline kat & to bite & & katnrog & to try by biting \\
\hline $\min$ & to drink & & minnrog & to taste by drinking \\
\hline pam & to eat & & pamnrog & to taste by eating \\
\hline preg & to make, do & & pregnrog & to try \\
\hline kat & to bite & + sok to jump, & katsok & to bite hard \\
\hline kel & to hold tight & to collide & kelsok & to hold tight \\
\hline mot & to tie & & motsok & to tie well \\
\hline mro & to think & & mrosok & to think carefully \\
\hline nер & to throw & & nepsok & $\begin{array}{l}\text { to weigh something } \\
\text { down with stones }\end{array}$ \\
\hline le & to look & + tae to know & letae & to recognise by seeing \\
\hline mro & to think & & mrotae & to recognise \\
\hline nrog & to feel, smell & & nrogtae & $\begin{array}{l}\text { to recognise } \\
\text { by smelling }\end{array}$ \\
\hline kul & to blanket & $\begin{array}{l}+k o r \text { to cover, } \\
\text { to block }\end{array}$ & kulkor & $\begin{array}{l}\text { to cover with } \\
\text { a blanket }\end{array}$ \\
\hline
\end{tabular}

5 TAM is used as a conventional abbreviation for markers of modality and aspect but is slightly misleading as there is no tense marking in South Efate. 


\begin{tabular}{llll} 
kus & to hide & kuskor & to cover-hide \\
lao & to stand up & laokor & to obstruct \\
pal & to be empty & palkor & to mourn \\
\hline
\end{tabular}

Examples of some of these compound verbs are given below, but first, to show that the second verb can act as a main verb in its own right, I give examples of the second verb in Table 3 acting as a main verb.

(7)
$\tilde{P} a=$ nrog- $-\varnothing$ - $?$
$\tilde{P} a=$ nrog nal-e- $n$ ?

2SG.IRS=hear-TR-3SG.OBJ 2SG.IRS=hear voice-V-3SG.POSS

$I=t l-i-\varnothing \quad$ na mes $k e=f o \quad$ pam-kit.

3SG.RS=tell-TR-3SG.OBJ COMP today 3SG.IRR=PSP.IRR eat-2PL.OBJ

'Do you hear? Do you hear his voice? He says he will eat you today.'

(98017bz, 2627.3, 2631.08)

(8)
Ntuam $i=l e k-a-\varnothing$
me $i=n a$
$k e=\boldsymbol{s o k}$.
devil 3SG.RS=look-TR-3SG.OBJ and 3SG.RS=begin.to 3SG.IRS=jump
'The devil looked at him and began to jump.'
(98017bz, 2775.9241, 2777.9496)

Examples of symmetrical compound forms follow.

(9) I=ta pi cost ni ntan mau, te-nen tuk=mas mro-tae.

$3 \mathrm{SG} . \mathrm{RS}=\mathrm{NEG}$ be cost of land NEG2 DET-that 1PL.INCL.RS $=$ must think-

know

'It is not the cost of the land, that is what we must recognise.'

(98016bz, 424.2799, 430.7801)

(10)
Nala, $k u=s l a t-i-\varnothing$.
$K u=m a i, \quad k u=$ mot-sok lak
vine 2 SG.RS=take-TR-3SG.OBJ 2 SG.RS=come 2 SG.RS=tie-jump pin
$k i-n$.
PREP-3SG.OBJ
'The vine, you take it. You come, you tie the lak (pin holding the canoe's outrigger to the cross-member) with it.' (004a, 650.5200, 658.2600)

\subsubsection{Asymmetrical compounds}

The second stem in an asymmetrical compound cannot occur independently as a verb, but combines productively with a number of verbs, often with a predictable meaning as can be seen in Table 4. Some of these compounds occur frequently and are conventionalised so that they behave as lexical items in their own right (and should be treated, for example, as headwords in the lexicon). Others are less conventionalised and allow for a certain amount of speaker creativity. The resulting compound verb is ambitransitive, regardless of whether the first verb is intransitive or ambitransitive. In some cases the second stem is an adverb (perkat 'really'), or a preposition (reki 'for') and in a small sample the second part can be a noun as we will see below.

In some cases we can call the second part of these compounds a verb because of the distributional pattern they share with known verbs, and because some have relic verbal status. For example, the form pun does not occur as a main verb in the data, but it is found (as fun) in the deverbal noun nafunwen 'killing fish by poisoning', suggesting 
either that it may still function as a verb, but not in the current data, or that the earlier verbal function is now only evident in compounds and this deverbal noun.

Table 4: Asymmetrical verb compounds

\begin{tabular}{|c|c|c|c|c|}
\hline \multicolumn{2}{|c|}{ Stem 1} & \multirow{2}{*}{$\begin{array}{l}\text { Stem } 2 \\
+ \text { pir negative (?) }\end{array}$} & \multicolumn{2}{|c|}{ Compound form } \\
\hline mro & to think & & mropir & to dislike \\
\hline nrog & to hear & & nrogpir & to disobey \\
\hline fis & to whip & + ktof to break & fisktof & to whip and break \\
\hline sak & to jump & & saktof & to jump and break \\
\hline kam & to step & & kamktof & to step on and break \\
\hline kat & to bite & & katktof & to bite and break \\
\hline kis & to press & + pun to kill & kispun & to abort a foetus \\
\hline$\tilde{p i}$ & to kick & & pipun & to kick kill \\
\hline pan & to burn & & panpun & to burn and kill \\
\hline sif & to club & & sifpun & to club and kill \\
\hline sok & to spear & & sokpun & to spear and kill \\
\hline
\end{tabular}

There are some compounds, listed below, for which the first stem is not attested in the data and so the semantics of the construction are not always transparent..

Table 5: Untransparent compounds

\begin{tabular}{llll}
\hline nril & + kau over (?) & nrilkau & to jump over \\
pal & & palkau & to step over \\
ta & takau & to trip over \\
lu & + pir negative (?) & lupir & to unroll \\
tka & & tkapir & to comb \\
sig & & sigpir & to ignore \\
\hline
\end{tabular}

Examples of these compound verbs follow.

I=lelu-kau kori me kori $i=$ tap leg-ki
3SG.RS=avoid-over dog but dog $3 \mathrm{SG} . \mathrm{RS}=\mathrm{NEG}$ be.straight-TR road NEG2
'He avoided the dog, but the dog was not right on the road.'
$(98017 \mathrm{~b}, 2766.1187,2769.0691)$

(13) $K u=k a n o \quad$ lek tesa i=sigpir.

2SG.RS=be.unable see child 3SG.RS=ignore

'You couldn't see a child ignore (its parent's voice).

(98007bz, 527.2600, 532.3201)

(14) Go naur nra nen, me mfiat $i=n a$

and island two that and snake 3SG.RS=begin.to

$i=$ fis-ktof-i-r.

3SG.RS=whip-break-TR-3PL.OBJ

'And those two islands, the snake began to split them.'

(98002az, 1833.92, 1838.08) 
As noted above, the second member of a compound can also be a noun, as seen in the examples in (15).

(15) oraik to fish (by spear or bow and arrow) (or 'to follow' aik 'fish')

pakmalep to mourn (pak 'go to' malep 'widow')

plakori to hunt for wild animals (plak 'with' kori 'dog')

(16) U=panpan patu oraik ur elau panpan tpfil 46 kaitau 1PL.RS=until stay fishing follow saltwater until blow.up 46 fish.sp. $r u=m a t$

3PL.RS=die

'They went fishing in the sea until we had dynamited 46 karong.' (021:27)

(17) Kau mil ru=lap pe lap. U=pan plakori. cow wild 3PL.RS=many INT many $1 \mathrm{PL} . \mathrm{EXCL}=\mathrm{go}$ hunt 'There were very many wild bullocks. We went hunting.' (98017bz, 1169.44, 1175.40)

In example (18) pi asel is a compound form which is transitivised with $-k i$ to introduce the Patient of the verb 'being a friend (to)'.

(18) Iwelkia $a=p o$ pi-asel-ki tete nanwei ni natkon. well 1SG.RS=PSP be-friend-TR some men of village 'Well I became friends of some boys in the village.' (98007az, 2474.0201, 2480.6200)

(19) To go tẫes ra=tme-r pi-asel-ki-r. fowl and swamphen 3DU.RS=RR-3PL.OBJ be-friend-TR-3PL.OBJ 'The chicken and the swamphen were friends.' (078:1)

Several $\mathrm{V}+\mathrm{N}$ compounds are based on the verb preg 'to make', resulting in intransitive verbs as in examples (20) and (21).

(20) Naĩer got ru=tok preg-nasum-ki lop. people black 3PL.RS=HAB make-house-TR bamboo 'Black people make houses from bamboo.' (17: 35 written example)

(21) I=piatlak natkon nen ru=mer preg-nafkal-ki-r. 3SG.RS=have village that 3PL.RS=again make-fight-TR-3PL.OBJ 'There are villages who keep fighting each other (make fight to them).' (089: 16)

The South Efate verb-noun compounds are not highly productive but they can be lexicalised via nominalisation. In fact, nominalisation provides further evidence in favour of the verb+noun acting as a unit; for example pi asel 'be friend' can be nominalised as a unit (nafiaselwen 'friendship'). which suggests that it forms a $\mathrm{V}+\mathrm{N}$ compound. 


\subsection{Pseudo-serial verbs}

As discussed in the introduction, there are four types of apparent verb combinations which can be excluded from consideration as serial verbs on distributional grounds. In this section I will outline what form these combinations take under the following headings: Adverbial modification of verbs (section 3.2.1); Prepositional verbs (section 3.2.2); Directional verbs and particles (section 3.2.3); and Auxiliary verbs (section 3.2.4).

\subsubsection{Adverbial modification of verbs}

Adverbial modification of verbs is manifested by two contiguous forms, one of which is a verb and the other an adverb. The only difference between adverbial modification and compounding (of a verb plus adverb) is the productivity of the combination of verb plus adverb and the conventionalised nature of the compound form. Adverbs are a word class independent of verbs and cannot function as verbs on their own. Example (22) illustrates the position of the adverb prakot 'anyhow' following the verb pes 'to speak'.

(22) Tija i=kano pan pes prakot, ke=mas pes taos teacher $3 \mathrm{SG} . \mathrm{RS}=$ cannot go speak anyhow $3 \mathrm{SG} . \mathrm{IRS}=$ must speak like nafsan leg language right

'The teacher can't speak any old how, he must use the right language.' (20001b, 648.1400, 651.9606)

The adverb termau 'for good' cannot occur on its own, but only ever functions as a modifier, as in (23).

(23)

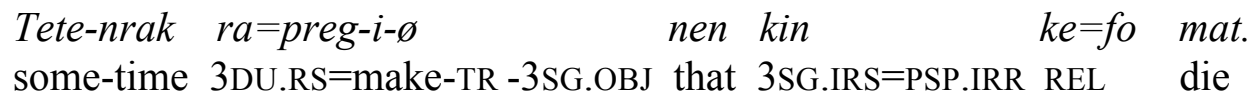

$K e=f_{0} \quad$ mat termau.

3SG.IRS=PSP.IRR die properly

'Sometimes they would make him die. He would die for good.' (98007az, 403.1599, 414.2600)

In (24) pelpel is an adverb modifying the preceding verb sef 'to escape' which follows the auxiliary verb tae 'be able'. This is the only example that has a different adverbial (pelpel 'quickly) and verbal (trapelpel 'be quick') form.

$$
\begin{aligned}
& \text { I=tae sef pelpel me katom } i=\text { kano. } \\
& \text { 3SG.RS=be.able escape quickly but crab 3SG.RS=unable } \\
& \text { 'He can escape quickly, but the hermit crab cannot.' } \\
& \text { (98009az, 57.4200, 60.2238) }
\end{aligned}
$$

These examples show that South Efate allows verb + adverb combinations that function in the same way as verb + verb in other languages but they cannot be regarded as being SVCs in South Efate.

\subsubsection{Prepositions and deverbal prepositions}

Prepositional verbs form a class which has been recognised for many Oceanic languages and which has been reconstructed by Pawley (1973: 142ff) for Proto Oceanic. Durie (1988a) suggests these verbs result from a diachronic drift from serial verb constructions. In South Efate the group of verbs shown in (25) can function as 
prepositions and so when they follow another verb there is some difficulty in identifying them as either prepositions or as the second verb in series. The task of identifying prepositions in this position is made more difficult because prepositions can take an object suffix in South Efate which makes them even more verb-like. These forms occur mainly in the position following a verb in the data.

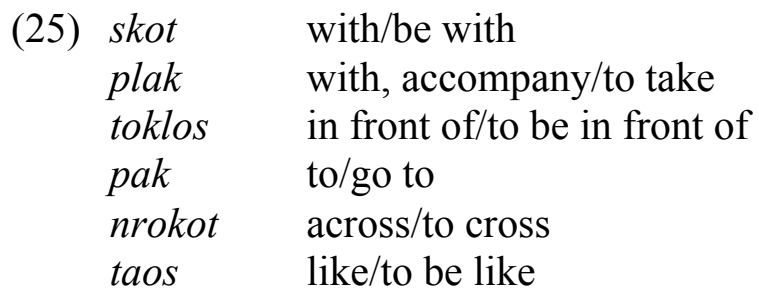

In the next example we see skot 'with/be with' acting clearly as a main verb (following a reflexive/reciprocal particle and so in a position that can only be filled by a verb), then, in (26) as a preposition between two nouns.

(26) Tesa nmatu me teas nanwei te-lap ru=tme-r child female and child male DET-many 3PL.RS=RR-3PL.POSS skot-i-r to me ru=ta lak mau. be.with-TR -3 PL.OBJ stay but 3PL.RS $=$ NEG marry NEG2 'Lots of girls and boys stay with each other, but they don't marry.' (98009a, 1178.039, 1188.06)

(27) Ale $u=p a k \quad$ namlas skot armi. ok 1PL.EXCL.RS=go.to bush with army 'Okay, we went to the bush with the army.' (98002az, 109.28, 112.82)

Thus verbs with prepositional functions in other languages have grammaticalised to become prepositions in South Efate and so do not participate in SVCs.

\subsubsection{Directional verbs and particles}

There are three directional verbs (using terminology from Durie 1988a: 11): pa 'go', $m a i$ 'come', and to 'stay' which are distinctive in that, in addition to acting as main and auxiliary verbs, they can occur following a noun, or, quite rarely, directly following a main verb. They can thus occur in a range of positions that is more extensive than that of other verbs. In this position following a main verb or a noun they specify a location or direction and do not act as verbs but as particles. In the next two examples mai 'come' acts first as a verb (immediately following the subject proclitic $r u=$ '3PL.RS') and then as a directional particle (following the noun raru 'canoe').

(28) Naik seserik ru=mai kai fam-lu nafnag wi. fish small 3PL.RS=come ECHO.SBJ eat-all food good 'The small fish came and ate all of the good food.' (005A, 996.9800, 1007.2400)

(29) Namer nen ru=pa raru mai. people that 3PL.RS=drive canoe hither 'Those people come by canoe.' (20003az, 29.9000, 34.7000) 
Given the distribution of directional particles following nouns we can similarly regard directional particles as modifiers when they occur following a verb, and not as verbs in series. It is only these directionals that can occur in this slot which is not available for verbs. Lynch, Ross and Crowley (2002a: 46) observe that directional particles of the kind discussed here are common in Oceanic languages and are "presumably derived from earlier directional serialisations", which I take to be the case for South Efate.

\subsubsection{Auxiliary verbs}

A small group of verbs appear in the PVC and have become grammaticalised as auxiliaries in this position. As each of these stems can also occur as main verbs, it appears that their function as auxiliary verbs results from a reinterpretation of an earlier serial verb construction. While this collocation of two verb stems appears to be a type of nuclear-layer serialisation, the auxiliary position can be distinguished structurally by its position before the slot in which a benefactive phrase can occur as shown in (30).

\section{(30) $\mathrm{S}=(\mathrm{PVC})($ AUX) $($ Benefactive phrase $) \mathrm{V}$}

The benefactive phrase in (31) follows the auxiliary verb tae 'to be able to' and precedes the main verb slat 'to take'.

$I=p i \quad$ esuan npalu=n $\quad$ i=tae
3SG.RS=be where brother=3SG.POSS 3SG.RS=be.able.to
nig tesa nanwei nega slat nafinaotan
of child male 3SG.POSS take chiefly.line
[BEN

'That is where his brother can take the chiefly line for his son.' $(53: 28)$

There is a small set of thirteen verbs (listed in Table 4) which occur in auxiliary position and which therefore do not participate in compounds or in serial verb constructions. The same verbs can also function with lower frequency as main verbs, but as auxiliary verbs they occur in a position which distinguishes them from main verbs. Auxiliary verbs occur with ordering restrictions that identify four groups, as shown in Table 5, with the first group ordered before the second and so on when they co-occur, although there is no example of all four co-occurring.

Significant for our current discussion is the fact that auxiliary verbs encode features of ability (tae 'be able to', kano 'be unable to'), modality (lakor 'maybe', mas 'must', nrus 'just', traem 'try'), direction (ler 'return', mai 'come', pan 'go', to 'stay', 'be at') and sequentiality (mer 'again', $p e i$ 'first') which are typical of the semantics of SVCs (e.g. the categories of directional, sequential, and manner as outlined in Crowley 2002a, or Lynch, Ross \& Crowley 2002: 47). As typological discussions of serial verbs often refer to the semantic types of verbs that can be serialized, it is important to note that these features are encoded by the auxiliary in South Efate and not in SVCs. 
Table 6: Auxiliary verbs

\begin{tabular}{|c|c|c|c|c|c|c|}
\hline & & 2 & & 3 & & \\
\hline \multirow{10}{*}{\multicolumn{2}{|c|}{ again, }} & kano & be unable to & ler return & $m a i$ & come \\
\hline & & lakor & maybe & & pan & go \\
\hline & & mal & not want to & & & \\
\hline & & mas & must & & & \\
\hline & & nrus & just & & & \\
\hline & & pei & first & & & \\
\hline & & traem & try & & & \\
\hline & & tae & know, be able to & & & \\
\hline & & $t o^{6}$ & do habitually & & & \\
\hline & & & (HAB) & & & \\
\hline
\end{tabular}

To illustrate the function of auxiliary verbs, consider (32) in which the benefactive phrase is present, represented by the pronoun gag '2SG.BEN', showing that the auxiliary verb kano 'be unable to' occurs in the preverbal complex distinct from a main verb position.
(32) $A=$ kano
gag saen.
1SG.RS=be.unable 2SG.BEN sign
'I can’t sign for you.' (98017az, 176.1464, 177.7206)

Now consider the following example in which a hash (\#) indicates the position at which a benefactive phrase could occur and so is the rightmost boundary of the preverbal complex. In (33) the direction of the motion encoded in the verb lek 'to look' is given by the auxiliary mai 'come'.

$$
\begin{aligned}
& \text { (33) } R u=\text { preg munwei } r u=m a i \quad \# \text { lek-a-ø. } \\
& \text { 3PL.RS }=\text { make healer 3PL.RS=come look-TR-3SG.OBJ } \\
& \text { 'They got the healer, they came to look at it (the spirit that would be } \\
& \text { exorcised).' (98011a, 1525.5001, 1528.0005) }
\end{aligned}
$$

Auxiliary verbs occur in a distinctive slot that permits the intrusion of a benefactive phrase between erstwhile verb + verb positions and thus cannot be analysed as participating in a serial verb construction.

\section{Conclusion}

In this paper we have seen that a number of structures that appear superficially analysable as serial verb constructions in South Efate are in fact not serial verbs. The reanalysis of directional verbs as directional particles and the use of prepositional verbs are well-known features in Oceanic that are reiterated in South Efate. The development of a class of auxiliary verbs has taken over much of the role associated with nuclearlayer serialisation in languages to the north. All of these phenomena contribute to the

6. The habitual to can occur after some members of its own group 2 (tae to, mal to) which may, with more data, require the specification of a further slot between 2 and 3 in Table 1. 
observation of the dissolution of serial verbs as one moves south in Vanuatu from the Paamese model that is more or less canonical to the southern Vanuatu languages displaying little serialisation. The fact that South Efate shares these features with southern languages suggests that the earlier assignment of South Efate to the Proto Central Vanuatu subgroup needs the kind of reanalysis recently proposed by Lynch (2004b). 


\section{University Library}

- MINERVA A gateway to Melbourne's research publications

Minerva Access is the Institutional Repository of The University of Melbourne

Author/s:

Thieberger, $\mathrm{N}$

Title:

The demise of serial verbs in South Efate

Date:

2007

Citation:

Thieberger, N. (2007). The demise of serial verbs in South Efate. In J. Siegel, J. Lynch \& D.

Eades (Eds.), Language description, history and development: linguistic indulgence in memory of Terry Crowley (pp. 237-251). Amsterdam : John Benjamins Publishing Company.

Publication Status:

Published

Persistent Link:

http://hdl.handle.net/11343/31824

File Description:

The demise of serial verbs in South Efate 


\section{University Library}

\section{- M M I N E R VA A gateway to Melbourne's research publications}

Minerva Access is the Institutional Repository of The University of Melbourne

Author/s:

THIEBERGER, N

Title:

The demise of serial verbs in South Efate.

Date:

2007-03-14

Citation:

THIEBERGER, N. (2007). The demise of serial verbs in South Efate.. Siegel, J (Ed.). Lynch, $J(E d$.). Eades, D (Ed.). Language Description, History and Development, Language Description, History and Development, (2007), pp.237-251. John Benjamins Publishing.

Persistent Link:

http://hdl.handle.net/11343/31292 